\title{
Influence of Self Efficacy and Academic Stress on Process Skills in Physics of Higher Secondary School Students in Malappuram and Kozhikode Districts
}

\author{
Roopa Gopal V. ${ }^{1}$, Prof. (Dr.) P.K. Aruna ${ }^{2}$ \\ 1 (Research Scholar, Department of Education, University of Calicut) \\ 2 (Professor, Department of Education, University of Calicut)
}

\begin{abstract}
The study was to find out the influence of self efficacy and academic stress on process skills in physics of higher secondary school students. The study adopted survey method and a representative sample of 505 higher secondary school students were selected by the stratified random sampling technique. The tools developed by the investigators for the study was Self efficacy Scale, Academic Stress Inventory and test of process skills in physics. The statistical techniques used were Pearson's Product moment Co-efficient of correlation and Two-way-ANOVA with $3 \times 3$ factorial design. The results show that main effect of self efficacy and Academic stress on Process skills in physics is significant, implies that the levels of Process skills in Physics is different for different levels of independent variables, self efficacy and Academic stress.
\end{abstract}

Key words- Self Efficacy, Academic Stress and Process Skills in Physics

\section{INTRODUCTION}

The students of $21^{\text {st }}$ century are facing many challenges in education, calling for greater attention from society. They wanted to perform various roles, many of which are undefined, inconsistent and unachievable in the present socio-cultural, economic and bureaucratic contexts of our society, causing heavy chaos on students, mainly higher secondary school students. Academic Stress is an area which is very hard to avoid in educational field. It is discussed not only in our daily conversations but has become enough of a notable public issue to attract widespread attention, especially for higher secondary school students. Academic stress is defined as "the mental distress with respect to some anticipated frustration associated with academic failure or even unawareness to the possibility of such failure" (Abouscie, 1994)..

A strong sense of efficacy enhances human accomplishment and mental health in many ways. "Self-efficacy is defined as a self-evaluation of one's competence to successfully execute a course of action necessary to reach desired outcomes"(Bandura, 1977, 1982). People with high assurance in their capabilities approach difficult tasks as challenges to be mastered rather than as threats to be avoided. They approach challenging situations with aspiration that they can get control over them. Such an efficacious outlook produces personal accomplishments and lowers the threat of depression. Science process skills are the skills that students use to investigate and explore the world around them and to construct and explain new science concepts. So it's very important for students to have a good understanding of these skills. However, identifying and defining the process Skills are not always a simple task. Strawitz (1993) defined science process skills (SPS) as "intellectual skills together with the associated learned capabilities which scientists use as a self-management procedure in carrying out their activities".

This present study examines the joint and individual effect of two variables, self-efficacy and academic stress on process skills in physics. Both of these factors have been examined extensively as predictors of academic adjustment, but here investigator focus explicitly on assessing the relative importance of these two variables in explaining student's success in attaining different process skills in physics.

\section{STATEMENT OF THE PROBLEM}

Influence of Self Efficacy and Academic Stress on Process Skills in Physics of Higher Secondary School Students in Malappuram and Kozhikode Districts 
III.

The present study involved following variables

\section{VARIABLES OF THE STUDY}

\subsection{Independent Variables}

For the present study Self-Efficacy and Academic Stress was selected as independent variables.

3.2 Dependent Variable

Process Skills in Physics was taken as dependent variable

\section{OBJECTIVES}

1. To find out the influence of independent variables self efficacy and academic stress on dependent variable process skills in physics of total sample.

2. To find out the extent of relationship between independent variable self efficacy and dependent variable process skills in physics of total sample and sub samples of boy, girl, urban, rural, Government and aided.

3. To find out the extent of relationship between independent variable Academic stress and dependent variable process skills in physics of total sample and sub samples of boy, girl, urban, rural, Government and aided.

4. To find out the main and interaction effect of independent variables self efficacy and academic stress on dependent variable process skills in physics for total sample.

\section{HYPOTHESES OF THE STUDY}

1. There will be significant relationship between independent variable self efficacy and dependent variable process skills in physics for total sample and sub samples of boy, girl, urban, rural, Government and aided.

2. There will be significant relationship between independent variable Academic stress and dependent variable process skills in physics of total sample and sub samples of boy, girl, urban, rural, Government and aided.

3. The main effect and interaction effect of independent variables self efficacy and academic stress on dependent variable process skills in physics will be significant for the total sample.

\subsection{Method}

\section{METHODOLOGY}

The normative survey method is used for the study.

\subsection{Instruments Used}

\subsubsection{Academic Stress Inventory (Aruna \& Roopa, 2015)}

The investigator choose 8 dimensions of Academic stress, Teacher's stress, Result stress, Test stress, Studying in group stress, Peer stress, Time management stress, Self inflicted stress and Parent's stress. The value of test re-test reliability coefficient is 0.74 so it is evident that the present Academic stress inventory is a reliable one. The Academic stress Inventory has been validated by the method of construct validity.

\subsubsection{Self efficacy Scale (Aruna \& Roopa, 2015)}

The investigator decided to choose 5 dimensions of Self efficacy. Social self efficacy, Self efficacy for academic achievement, Self regulatory efficacy, Self efficacy to meet others expectation, Self efficacy for leisure time skills and extracurricular activities. The value of test re-test reliability coefficient is 0.79 so it is evident that the present self efficacy scale is a reliable one. The self efficacy scale has been validated by the method of construct validity.

\subsubsection{Test of Process Skills in Physics (Aruna, Roopa \& Abida, 2015)}

The investigators decided to select 8 process skills including 5 basic skills and 3 integrated skills. Observing, Inferring, Measuring, Classifying, Predicting, Formulating hypothesis, Interpreting data and Experimenting. The value of test re-test reliability coefficient is 0.68 and Content validity is established in this test.

\subsection{Sample Used}

A sub set of the population selected for the observation and analysis is called a sample. The representative sample of 570 students of plus two classes of higher secondary school students have been selected from Malappuram and Kozhikode districts of Kerala. After scoring and consolidation, 505 samples were selected for final analysis. The sample selected by the stratified random sampling technique. The different strata of population selected on the basis of gender, locale and type of management of the schools. 


\section{STATISTICAL TECHNIQUES USED}

The following statistical techniques have been used for the analysis of data.

1. Pearson's Product moment Co-efficient of correlation. (Garrett, 1981).

2. Test of significance of ' $r$ ' at 0.05 and 0.01 level. (Ferguson, 1976).

3. Verbal description of correlation coefficient. (Garrett, 1996).

4. Two-way-ANOVA with $3 \times 3$ factorial design. (Ferguson, 1976).

5. Scheffé's test of post hoc comparison. (Ferguson, 1976).

\section{RESULTS AND DISCUSSION}

8.1 Results of Correlation Analysis between Independent and Dependent Variables

The results of correlation analysis between independent and dependent variables are described below.

TABLE 1Result of Relationship between Academic Stress and

Process Skills in Physics, Self efficacy and Process Skills in Physics of Higher Secondary

School Students for the Total Sample and the Subsamples Boy, Girl, Urban, Rural, Government and Aided.

\begin{tabular}{lcccrc}
\hline \multicolumn{1}{c}{ Sample } & $\mathrm{N}$ & $\begin{array}{r}\text { 'r' between SE } \\
\text { and PS }\end{array}$ & $\begin{array}{c}\text { 't' } \\
\text { value }\end{array}$ & $\begin{array}{c}\text { 'r' between } \\
\text { and PS }\end{array}$ & $\begin{array}{c}\text { 't' } \\
\text { value }\end{array}$ \\
\hline Total & 505 & 0.899 & $46.19^{* *}$ & -0.777 & $27.68^{* *}$ \\
Boy & 250 & 0.889 & $30.93^{* *}$ & -0.726 & $16.80^{* *}$ \\
Girl & 255 & 0.877 & $28.74^{* *}$ & -0.831 & $23.55^{* *}$ \\
Urban & 264 & 0.881 & $30.27^{* *}$ & -0.793 & $21.10^{* *}$ \\
Rural & 241 & 0.873 & $27.75^{* *}$ & -0.757 & $17.95^{* *}$ \\
Government & 244 & 0.871 & $27.69^{* *}$ & -0.733 & $16.76^{* *}$ \\
Aided & 261 & 0.897 & $32.71^{* *}$ & -0.816 & $22.73^{* *}$ \\
\hline
\end{tabular}

The correlation analysis revealed that the relationship between independent variable Self efficacy and dependent variable Process skills in Physics is significant for total samples and relevant sub samples of Boy, Girl, Urban, Rural, Government and Aided even at 0.01 level. The relationship between independent variable Self efficacy and dependent variable Process skills in Physics is positive. That means when Self efficacy increases Process skills in Physics also increases.

The correlation analysis revealed that the relationship between Academic stress and Process skills in Physics is significant for total samples and relevant sub samples of Boy, Girl, Urban, Rural, Government and Aided even at 0.01 level. The relationship between independent variable Academic stress and dependent variable Process skills in Physics is negative. That means when Academic stress increases Process skills in Physics decreases.

8.2 Main and Interaction Effects of Self efficacy and Academic Stress on Process Skills in Physics of Higher secondary School Students for Total Sample

Two-way ANOVA with $3 \times 3$ Factorial Design was employed for total sample to find out the main and interaction effects of self efficacy and Academic stress on Process skills in Physics of Higher secondary school students. Summary of Two-way ANOVA for total sample is present in the Table 2

TABLE 2Summary of Two-way ANOVA of Process Skills in Physics by Self Efficacy and Academic Stress for the Total Sample

\begin{tabular}{lccccc}
\hline \multicolumn{1}{c}{ Source of variation } & $\begin{array}{c}\text { Sum of } \\
\text { Squares }\end{array}$ & df & $\begin{array}{c}\text { Mean } \\
\text { Squares }\end{array}$ & $\begin{array}{c}\text { F- } \\
\text { Value }\end{array}$ & $\begin{array}{c}\text { Level of } \\
\text { Significance }\end{array}$ \\
\hline $\begin{array}{l}\text { Self efficacy } \\
\text { Academic stress }\end{array}$ & 3765.899 & 2 & 1882.95 & 97.44 & 0.01 \\
$\begin{array}{l}\text { Two-way interaction } \\
\text { self efficacy and }\end{array}$ & 1706.96 & 2 & 853.48 & 44.16 & 0.01 \\
$\begin{array}{l}\text { academic stress on } \\
\text { process skills in }\end{array}$ & 1872.89 & 4 & 468.22 & 24.23 & 0.01 \\
$\begin{array}{l}\text { Physics } \\
\quad \text { Total }\end{array}$ & 207338.00 & 506 & & & \\
\hline
\end{tabular}

\subsubsection{Main Effect of Self efficacy}

As per the table 2 the F value obtained for the Main Effect of Self efficacy on Process Skills in Physics of Higher secondary school students for the Total sample was found to be 97.44 and is found beyond the tabled

DOI: $10.9790 / 0837-2202056973 \quad$ www.iosrjournals.org $\quad 71 \mid$ Page


value for 2 degrees of freedom at 0.01 level of significance. Therefore, the main effect of Self efficacy on Process Skills in Physics for total sample is significant. Hence the Process Skills in Physics of Higher secondary school students for the total sample is dependent up on the changes in the Self efficacy of the students.

\subsubsection{Main Effect of Academic Stress}

As per the table 2 the F value obtained for the Main Effect of Academic stress on Process Skills in Physics of Higher secondary school students for the Total sample was found to be 44.16 and is found beyond the tabled value for 2 degrees of freedom at 0.01 level of significance. Therefore, the main effect of Academic stress on Process Skills in Physics for total sample is significant. Hence the Process Skills in Physics of Higher secondary school students for the total sample is dependent up on the changes in the Academic stress of the students.

\subsubsection{Interaction Effect of Self Efficacy and Academic Stress}

As per the table 2, the obtained F-value for the Interaction Effect of Self efficacy and Academic stress on Process Skills in Physics is also found to significant at 0.01 level. From the result it can be inferred that the Process Skills in Physics of Higher secondary school students vary with regard to the combined effect of Self efficacy and Academic stress.

\subsubsection{Scheffés Test of Multiple Comparisons for Comparing the Different Groups based on Different} Level of the Independent Variable

As per ANOVA table the independent variables Self efficacy and Academic stress were found to have significant main effect on dependent variable Process skills in Physics. To identify the groups which create the main effect, Scheffés test of Post-hoc comparison was applied.

Results of comparison between mean scores of process skills in physics based on three levels of Self efficacy and academic stress for total sample are given in Table 3

TABLE 3Result of Scheffés Test of Post-hoc Comparison between Mean of Scores of

Process Skills in Physics Based on Three Groups of Self Efficacy and Academic Stress for Total Sample

\begin{tabular}{|c|c|c|c|c|c|c|c|}
\hline \multirow{2}{*}{$\begin{array}{c}\text { Independent } \\
\text { Variable }\end{array}$} & \multirow{2}{*}{$\begin{array}{l}\text { Groups } \\
\text { Computed }\end{array}$} & \multicolumn{2}{|c|}{ Means } & \multirow{2}{*}{$F$} & \multirow{2}{*}{$\begin{array}{l}\text { Lower } \\
\text { Bound }\end{array}$} & \multirow{2}{*}{$\begin{array}{l}\text { Upper } \\
\text { Bound }\end{array}$} & \multirow{2}{*}{$\begin{array}{c}\text { Level of } \\
\text { Significance }\end{array}$} \\
\hline & & $\mathrm{M}_{1}$ & $\mathrm{M}_{2}$ & & & & \\
\hline \multirow{3}{*}{ Self Efficacy } & LSE-ASE & 6.64 & 17.955 & 11.30 & -12.59 & -10.02 & 0.01 \\
\hline & LSE-HSE & 6.64 & 29.70 & 23. & -24.62 & -21.17 & 0.01 \\
\hline & ASE-HSE & 17.955 & 29.70 & 11.74 & -12.99 & -11.93 & 0.01 \\
\hline \multirow{3}{*}{$\begin{array}{l}\text { Academic } \\
\text { Stress }\end{array}$} & LAS-A & 28.06 & 18.82 & 9.24 & 7.93 & 10.54 & 0.01 \\
\hline & LAS-H & 28.06 & 6.89 & 21. & 19. & 22.78 & 0.01 \\
\hline & AAS-HAS & 18.82 & 6.89 & 11.93 & 10.66 & 13.19 & 0.01 \\
\hline
\end{tabular}

LSE- Low Self efficacy

LAS-Low Academic Stress

HSE- High Self efficacy

ASE- Average Self efficacy

AAS-Average Academic Stress

From the Table 3, it is clear that for the variable self efficacy, the F-ratio obtained for LSE-ASE, LSEHSE and ASE-HSE are 11.30, 23.05 and 11.74 respectively. Significant mean difference at 0.01 level is noticed for all groups where the obtained F- ratio exceed the limit set for $\mathrm{F}$ at 0.01 level of significance.

From the Table 4, it is clear that for the variable Academic stress, the F- ratio obtained for LSE-ASE, LSE-HSE and ASE-HSE are 9.24, 21.17 and 11.93 respectively. Significant mean difference at 0.01 level is noticed for all groups where, the obtained F- ratio exceed the limit set for $\mathrm{F}$ at 0.01 level of significance.

\section{CONCLUSION}

Self efficacy and Academic stress are very important factors in determining educational success of a student. The major objective of the study is to find out the influence of Self efficacy and Academic stress on Process skills in Physics of Higher secondary school students. This was found out by making minor objectives. The objectives were tested through different statistical techniques like Coefficient of correlation, Two way analysis of variance. From the correlation analysis it was found that Self efficacy have positive significant correlation with Process skills in physics and the result is in agreement with those of Motlagh et al. (2011). Academic stress has negative significant correlation with Process skills in Physics. The major finding of the study is that Self efficacy and Academic stress have significant effect on Process skills in physics. The results show that main and interaction effect of self efficacy and Academic stress on Process skills in physics is significant, implies that the levels of Process skills in Physics is different for different levels of independent variables, self efficacy and Academic stress. 


\section{EDUCATIONAL IMPLICATION}

The study reveals that self efficacy and academic stress have significant influence on process skills in physics. Based on the results obtained from the present study some of the practical suggestions offered will be helpful for teachers as well as those who are interested in the development of the science education system.

- The study reveals that Self efficacy has a positive and Academic stress has a negative correlation with Process skills in physics. So parents and teachers should take necessary steps to develop Self efficacy and reduce the academic stress among students.

- Teacher support is helpful for students facing stress, no matter how well they are adaptable to the stress. Family members should try to understand their interests, specialties, and abilities so as to avoid having too high expectations of them and causing them additional stress.

- Reinforcement by teachers can influence student's self efficacy, because positive reinforcement conveys strong support on student abilities.

- Provide adequate guidance, counseling and other programs that can be designed to promote the psychological well- being of the students.

- Effort should be made by concerned authorities to provide adequate facilities such as class rooms, relaxation centers, good lab rooms and secure social environment so that the self efficacy can be enhanced and student's academic stress can be reduced to the minimum.

\section{REFERENCES}

[1] Abouscie, H. (1994). A conceptual formulations for research on stress: Stress at work. New York: Wiley.

[2] Bandura, A. (1977). Social learning theory. Englewood Cliffs: Prentice Hall.

[3] Bandura, A. (1982). Self-Efficacy mechanisms in human agency. American Psychologist, 37,122-147.

[4] Ferguson, G.A. (1976). Statistical analysis in psychology and education. Tokyo: McGraw Hill.

[5] Garrett, H.E. (1981). Statistics in psychology and education. Bombay: Vakils Feffer and Simons Ltd.

[6] Garrett, H.E. (1996). Statistics in psychology and education. Bombay: Vakils, Feffer and Simons Ltd.

[7] Motlagh, E.S., Amrai, K., Yazdani, J.M., Abderahim, A.H., \& Souri, H. (2011). The relationship between self-efficacy and academic achievement in high school students. Procedia Social and Behavioral Sciences, $15,765-768$.

[8] Strawitz, V. (1993). The effect of review on science process skill acquisition. Retrieved from ERIC Database (EJ 47761 4). 